\author{
Michal ŠPES ${ }^{1}$ \\ Lubomír BEŇA ${ }^{2}$ \\ Miroslav MIKITA ${ }^{3}$ \\ Michal MÁRTON ${ }^{4}$ \\ Henryk WACHTA ${ }^{5}$
}

\title{
VERIFICATION OF THE DISTANCE PROTECTION RELAY OPERATION
}

\begin{abstract}
This paper describes the possibilities of testing digital protection relay. Consequently, the SIEMENS SIPROTEC 7SA611 distance protection, its protection functions and its use for protection of the line are further characterized. At the end of the article, testing of this distance protection is described along with several variations of Advance distance module testing.
\end{abstract}

Keywords: distance protection relay, testing of operation, indirect method

\section{Introduction}

The electric power system is formed by generators that convert energy of rotating masses into electrical energy, equipment serving for the transformation, transmission and consumption of electricity [1].

Power system is characterized by:

- vastness - power system is spread over a particular space,

- complexity - between elements of active feedback,

- random nature of the load - not known in advance the load size.

${ }^{1}$ Michal Špes, Department of Electric Power Engineering at Technical University of Košice, Mäsiarska 74, 04120 Košice, 0042155602 3584, Michal.Spes@ tuke.sk

2 Lubomír Beňa, Department of Electric Power Engineering at Technical University of Košice, Mäsiarska 74, 04120 Košice, 0042155602 3561, Lubomir.Bena@tuke.sk

${ }^{3}$ Miroslav Mikita, Department of Electric Power Engineering at Technical University of Košice, Mäsiarska 74, 04120 Košice, 0042155602 3560, Miroslav.Mikita@tuke.sk

${ }^{4}$ Michal Márton, Department of Electronics and Multimedia Communications at Technical University of Košice, Park Komenského 13, 04120 Košice, Michal.Marton.3@student. tuke.sk

${ }^{5}$ Corresponding author: Henryk Wachta, Politechnika Rzeszowska, Katedra Energoelektroniki, Elektroenergetyki i Systemów Złożonych, ul. W. Pola 2, 35-959 Rzeszów, 17865 1977, hwachta@prz.edu.pl 
Due to the rapid transition process, the operational reliability and safety of the power system depend not only on the most advanced technologies and knowledge, but also on the appropriate choice of protective devices [2].

Prior to the introduction of protective devices and relays, functional and system testing of the correct operation of these devices must be carried out before they are put into service.

The conclusion of such a test is usually the test report, which includes the results of the operation verification of the individual protective functions that protect the device against fault condition, which may occur after putting into operation [2], [4].

\section{Method of verifying the operation of protective devices}

In order to verify the operation of the protective devices, we can identify two test methods:

- direct method,

- indirect method.

The connection of protective devices is realized via instrument transformers. In terms of construction, different voltage levels and different current it is not appropriate to dimension individual devices for each protected object. For these reasons, protective devices and terminals are connected via instrument transformers.

Depending on the chosen measured quantity we use current transformers (overcurrent protection), voltage transformers (overvoltage / undervoltage protection), or combinations thereof (distance protection). In terms of choice of instrument transformers current it is crucial for us the location of protection relay from attachment sites in substations. For long supply lines it is necessary to respect the losses that arise when supplying the protection with long feeds. Therefore, it is necessary to choose the current transformer with secondary current value of $1 \mathrm{~A}$ [3].

In case there can be a loss of transmitted secondary current, we choose a current instrument transformer with a secondary current value of $5 \mathrm{~A}$.

The voltage transformers secondary side is $100 \mathrm{~V}$. From these facts, it is inferred indirect assay method. The test device injects secondary voltage / current until the protection relay responds [3].

\section{Distance protection relay 7SA611}

The SIPROTEC 47SA611 distance protection relay is a universal relay for protection, control and automation with a 4-line display on the basis of the SIPROTEC 4 system. Its high level of flexibility makes it suitable to be implemented at all voltage levels [5]. 
Digital distance protection relay is equipped with features that are typically used for line protection and is therefore universally applicable. It is also possible to use the device as a time lapse backup protection to all kinds of protective devices operating on the principle of comparing for the lines, transformers, generators, motors and busbars of all voltage levels [5].

Typical features of protection relay SIPROTEC 7SA611:

- high-speed tripping time,

- impedance setting range allows very small settings for the protection of very short lines,

- self-setting detection for power swing frequencies up to $7 \mathrm{~Hz}$,

- current transformer saturation detector prevents non-selective tripping by distance protection in the event of CT saturation,

- phase-segregated teleprotection for improved selectivity and availability,

- digital relay-to-relay communication by means of an integrated serial protection data interface,

- adaptive auto-reclosure (ADT) [5] (Fig. 1).

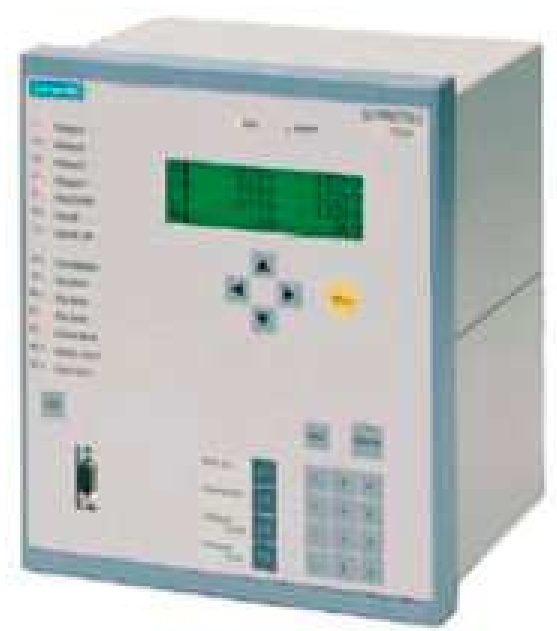

Fig. 1. Distance protection relay 7SA611 [5]

\subsection{Description of the functions of the distance protection relay 7SA611}

Distance protection relay 7SA611 includes features for protection of overhead lines and cable lines at all voltage levels from 5 to $765 \mathrm{kV}$. The unit may issue one or three-pole TRIP commands, and CLOSE commands. It is perhaps the single-pole, three-pole and more pole automatic reclosing. The device operates reliably and selectively even under the most burdensome power line conditions [5]. 
The Distance protection relay is equipped with the following protective functions:

a) the protection functions for protecting Earth-fault (ANSI 50N/ ANSI $51 \mathrm{~N} /$ ANSI $67 \mathrm{~N}$ ),

b) distance protection function (ANSI 21/ ANSI 21N),

c) overcurrent protection functions with a time delay, immediately acting protective functions and overcurrent protection functions with the direction (ANSI 50 / ANSI 51 / ANSI 67),

d) overvoltage and undervoltage protection function (ANSI 59/ ANSI 27),

e) overfrequency and underfrequency protection function (ANSI 81O/ ANSI 81U),

f) automatic reclosing (ANSI 79),

g) checking of the synchronization (ANSI 25),

h) protection of the failure of breaker (ANSI 50BF),

i) thermal protection (ANSI 49) [5].

In addition to protective functions, this digital protection terminal also has control and monitoring functions:

- Control function

The instrument has extensive control functions, such as instrumentation hardware as well as software. Measured values are continuously monitored.

- Management of functions

Function management is performed by the control center of the device. Coordinates the running of protection and ancillary functions, processes their decisions and the information coming from the device.

\section{Parameterization of Distance protection relay SIPROTEC 7SA611 in DIGSI software environment}

For parameterization and setting the Distance protection relay SIEMENS SIPROTEC 7SA611 is appropriate to use configuration program DIGSI 4. First, we need to create a new project that we call "SIPROTEC" for the sake of clarity. For proper configuration, you must add a digital terminal. In "SIPROTEC" we choose "Folder" through the main rail route Insert> DIGSI> Device SIPROTEC add protective relay (Fig. 2).

Consequently, it is necessary after opening the library for the digital protective terminal we specify the parameters of protection, we use the nameplate (Fig. 3). 


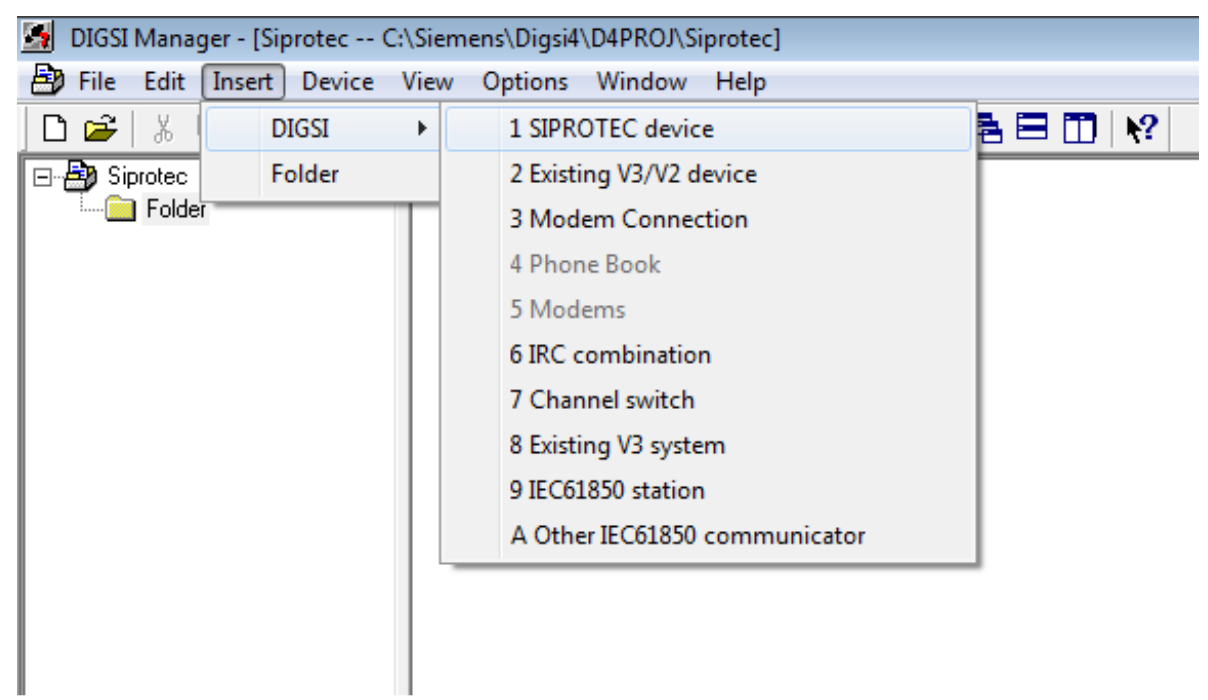

Fig. 2. Adding digital protective relay in the software environment

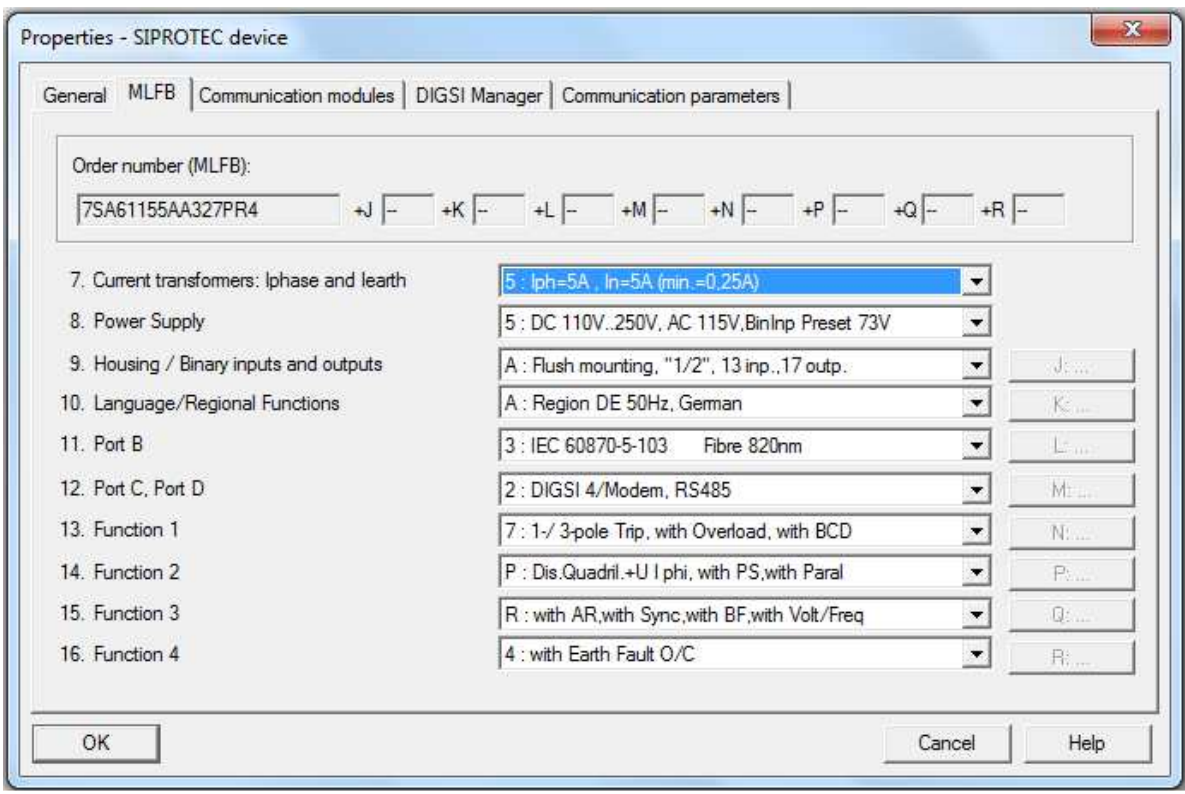

Fig. 3. Setting the basic parameters of protection relay according to nameplate

After this step, we can proceed to parameterization of the distance protection and the setting of protective functions (Fig. 4). Our role in terms of protecting is to set parameters for digital protection relay of the $110 \mathrm{kV}$ line (V6834) in 
substation Kechnec (it is a part of the $110 \mathrm{kV}$ distribution system in Eastern Slovakia).

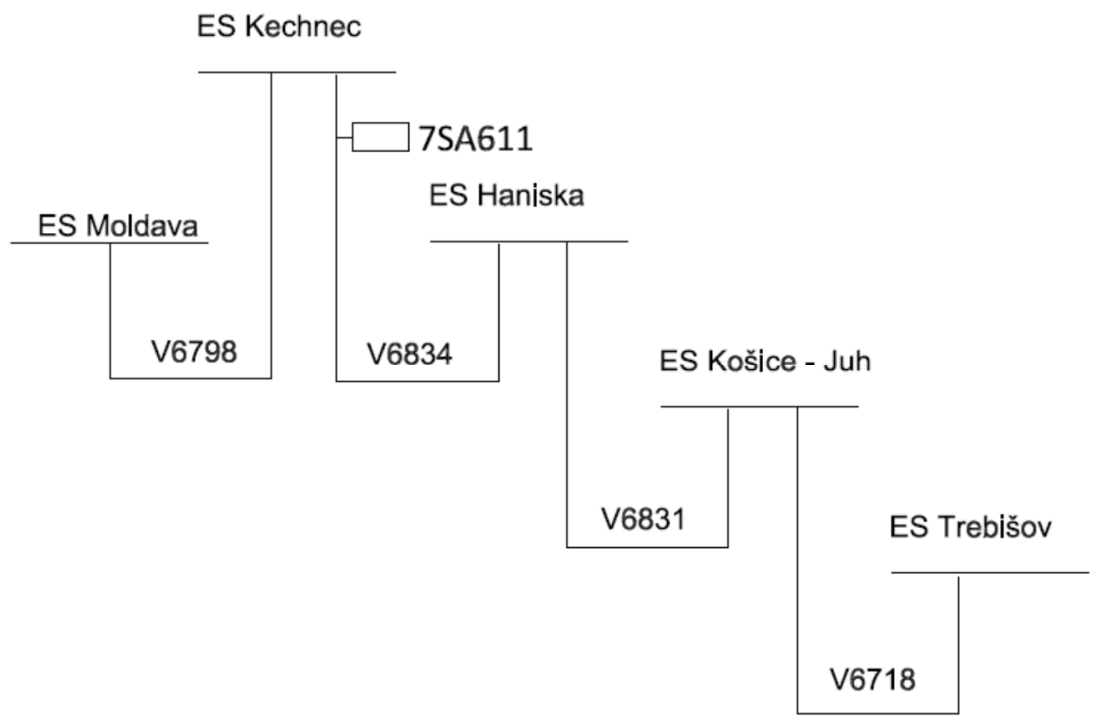

Fig. 4. The topology of the protected electricity grid

Firstly, it is necessary to define the various transfers of instrument transformers. Since we choose the setting parameters for the $110 \mathrm{kV}$ line it is necessary to select a voltage transformer with primary voltage value of $110000 \mathrm{~V}$.

In the case of current transformers, the value of the current on the secondary side is for us $I_{2 N}=5 \mathrm{~A}$.

Before setting individual zones, you must first define protected zones and lines:

- Zone 1: In this zone is impedance-adjusted at $85 \%$ of line impedance V6834,

- Zone 2: In this zone is impedance-adjusted at $100 \%$ of line impedance V6834 and 60\% of line impedance V6831,

- Zone 3: In this zone is impedance-adjusted at $100 \%$ of line impedance V6834, $100 \%$ of line impedance V6831 and $40 \%$ of line impedance V6718,

- Zone 4: This zone is backward zone and the impedance is adjusted at $30 \%$ of line impedance V6718,

- Zone 5: In this zone is impedance-adjusted at $100 \%$ of line impedance V6834, 100\% of line impedance V6831 and $100 \%$ of line impedance V6718.

- Zone 6: This zone is not activated. 
The configuration of individual zones are as follows (Table 1-3):

Table 1. Setting Zone 1 and Zone 2

\begin{tabular}{|c|c|c|c|}
\hline Zone & Z1 & Zone & Z2 \\
\hline Status & Active & Status & Active \\
\hline Direction & Forward & Direction & Forward \\
\hline Charakteristics & Polygon & Charakteristics & Polygon \\
\hline Values & Secondary & Values & Secondary \\
\hline$X_{1}$ & $0.196 \Omega$ & $X_{2}$ & $0.420 \Omega$ \\
\hline$R_{1}, \mathrm{PG}$ & $0.181 \Omega$ & $R_{2}, \mathrm{PG}$ & $0.405 \Omega$ \\
\hline$R_{1}, \mathrm{PP}$ & $0.060 \Omega$ & $R_{2}, \mathrm{PP}$ & $0.135 \Omega$ \\
\hline$\alpha_{1}$ & $70^{\circ}$ & $\alpha_{2}$ & $70^{\circ}$ \\
\hline$t_{1}$ & $0 \mathrm{~s}$ & $t_{2}$ & $0.5 \mathrm{~s}$ \\
\hline
\end{tabular}

Table 2. Setting Zone 3 and Zone 4

\begin{tabular}{|c|c|c|c|}
\hline Zone & Z3 & Zone & Z4 \\
\hline Status & Active & Status & Active \\
\hline Direction & Forward & Direction & Backward \\
\hline Charakteristics & Polygon & Charakteristics & Polygon \\
\hline Values & Secondary & Values & Secondary \\
\hline$X_{3}$ & $0.896 \Omega$ & $X_{4}$ & $0.152 \Omega$ \\
\hline$R_{3}$, PG & $0.935 \Omega$ & $R_{4}, \mathrm{PG}$ & $0.141 \Omega$ \\
\hline$R_{3}, \mathrm{PP}$ & $0.311 \Omega$ & $R_{4}, \mathrm{PP}$ & $0.047 \Omega$ \\
\hline$\alpha_{3}$ & $70^{\circ}$ & $\alpha_{4}$ & $70^{\circ}$ \\
\hline$t_{3}$ & $1 \mathrm{~s}$ & $t_{4}$ & $0.5 \mathrm{~s}$ \\
\hline
\end{tabular}

Table 3. Setting Zone 5 and Zone 6

\begin{tabular}{|c|c|c|c|}
\hline Zone & Z5 & Zone & Z6 \\
\hline Status & Active & Status & Non Active \\
\hline Direction & Forward & Direction & - \\
\hline Charakteristics & Polygon & Charakteristics & - \\
\hline Values & Secondary & Values & - \\
\hline$X_{5}$ & $1.420 \Omega$ & $X_{6}$ & - \\
\hline$R_{5}, \mathrm{PG}$ & $1.537 \Omega$ & $R_{6}, \mathrm{PG}$ & - \\
\hline$R_{5}, \mathrm{PP}$ & $0.512 \Omega$ & $R_{6}, \mathrm{PP}$ & - \\
\hline$\alpha_{5}$ & $70^{\circ}$ & $\alpha_{6}$ & - \\
\hline$t_{5}$ & $5 \mathrm{~s}$ & $t_{6}$ & \\
\hline
\end{tabular}




\section{Verification of the operation of digital protections relay SIEMENS SIPROTEC 7SA611}

After setting and saving parameters in the protection relay we proceeded to verify the operation of the protection relay through device CMC 156. To verify the operation of protection relay SIPROTEC 7SA611 we used the module "Advance distance". In order to test the protection, we also need to set up protection zones in the "Advance distance" module. This is possible in two ways.

The first method is to manually set the zones. We will fill in all the necessary data based on the set values in the protection relay. Each zone we create using points and then we assign zones tripping times.

The first method is rather tedious. Therefore, it is possible to create individual protection zones by exporting the rio file with the DIGSI, which is consequently recorded in "test objects parameters" in the "Advance distance" module. After setting all the necessary parameters and zones we can choose the fault to be tested, we can select the points to be tested, or search zones (Fig. 5).

Testing digital protective relay was performed for interphase short circuit L1-L2.

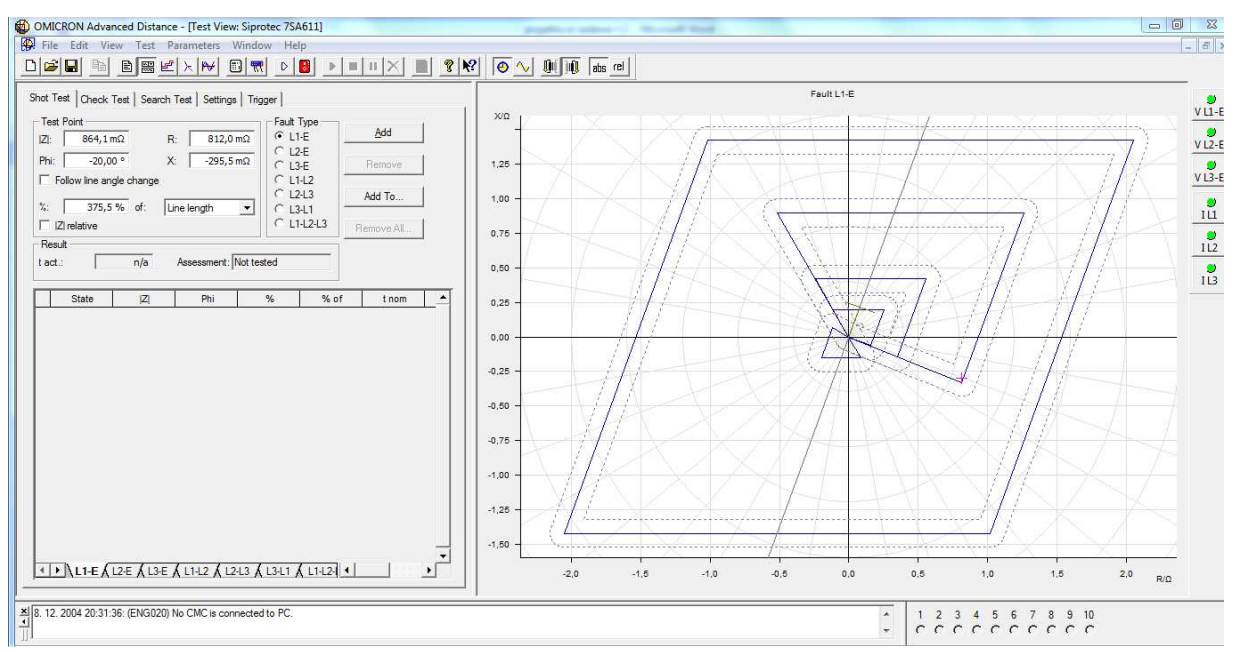

Fig. 5. Testing in the module Advance distance

\subsection{Verification of the operation of digital protection relay SIEMENS SIPROTEC 7SA611 for individual test points}

The actual operation of the test equipment of protections relays CMC 156 is based on injection of voltages and currents in the protective relay, wherein the testing device monitors the reaction of the relay, and evaluates the actual test. 
In Test Universe software, you can choose several ways of testing. It is possible to select the manual input of the individual points in the zone it protects, and then track equipment's time of the protective relay for that fault.

Test points that we have entered can be seen in the figure below (Fig. 6). The results of the testing are in the table below (Table 4).

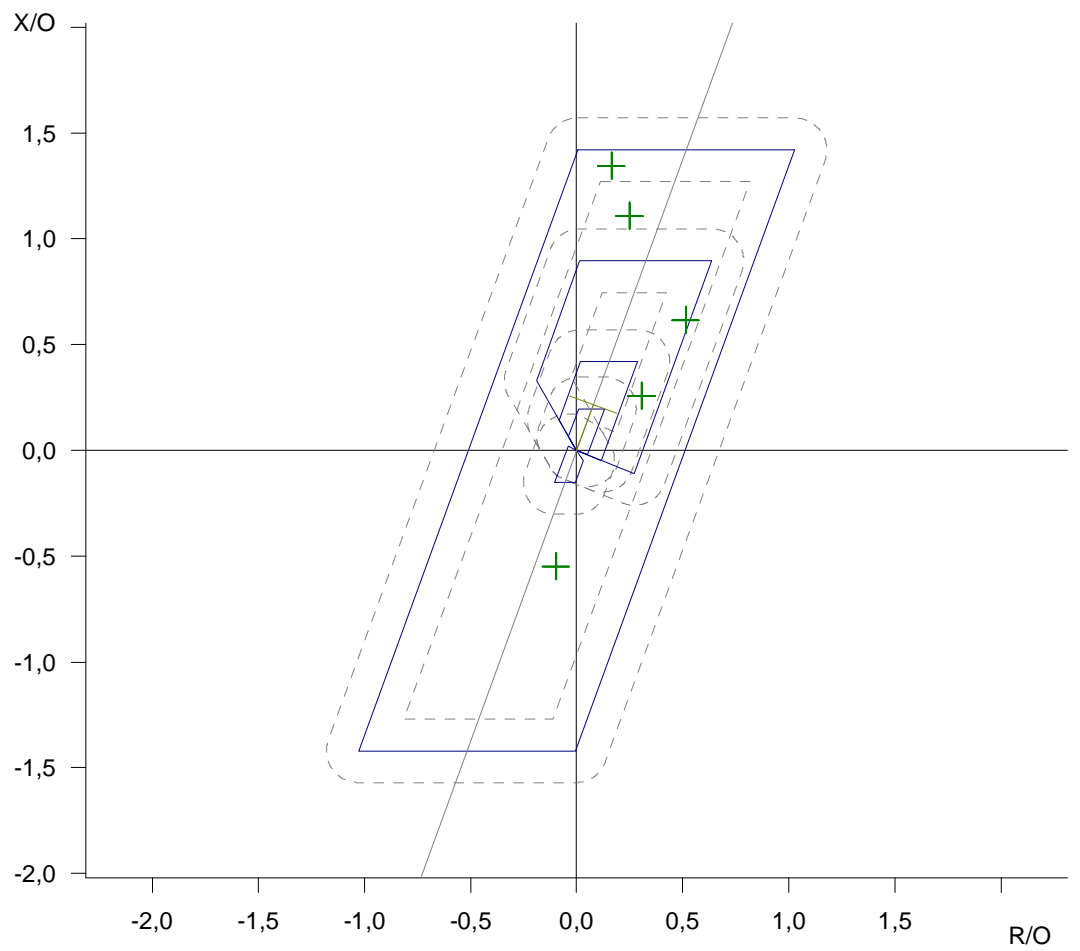

Fig. 6. Points for test of distance protection relay

Table 4. Results from testing of distance protection relay

\begin{tabular}{|c|c|c|c|c|c|c|c|}
\hline$|\mathbf{Z}|$ & Phi & $\%$ & tnom $_{\text {tact }}$ & Dev. & ITest & Result \\
\hline $1.352 \Omega$ & $83.07^{\circ}$ & n/a & $5.000 \mathrm{~s}$ & $5.034 \mathrm{~s}$ & $0.676 \%$ & $10.00 \mathrm{~A}$ & Passed \\
\hline $1.137 \Omega$ & $77.31^{\circ}$ & n/a & $5.000 \mathrm{~s}$ & $5.039 \mathrm{~s}$ & $0.788 \%$ & $10.00 \mathrm{~A}$ & Passed \\
\hline $800.0 \mathrm{~m} \Omega$ & $50.00^{\circ}$ & n/a & $1.000 \mathrm{~s}$ & $1.034 \mathrm{~s}$ & $3.41 \%$ & $10.00 \mathrm{~A}$ & Passed \\
\hline $400.0 \mathrm{~m} \Omega$ & $40.00^{\circ}$ & n/a & $1.000 \mathrm{~s}$ & $1.034 \mathrm{~s}$ & $3.41 \%$ & $10.00 \mathrm{~A}$ & Passed \\
\hline $558.2 \mathrm{~m} \Omega$ & $-100.00^{\circ}$ & n/a & $5.000 \mathrm{~s}$ & $5.034 \mathrm{~s}$ & $0.678 \%$ & $10.00 \mathrm{~A}$ & Passed \\
\hline
\end{tabular}

\subsection{Verification of the operation of digital protection relay SIEMENS SIPROTEC 7SA611 for a line of testing}

The second variant of testing is time easier. Unlike the first testing method, we do not select individual points of testing but we set "a line" points, first to the 
endpoint testing. Test points were not set individually, but the built-in line crossed all impedance zones. Test points on the line segment were generated by the module automatically. The results of the testing are shown in the table below (Table 5) and the line segment with the test points is in the figure (Fig. 7).

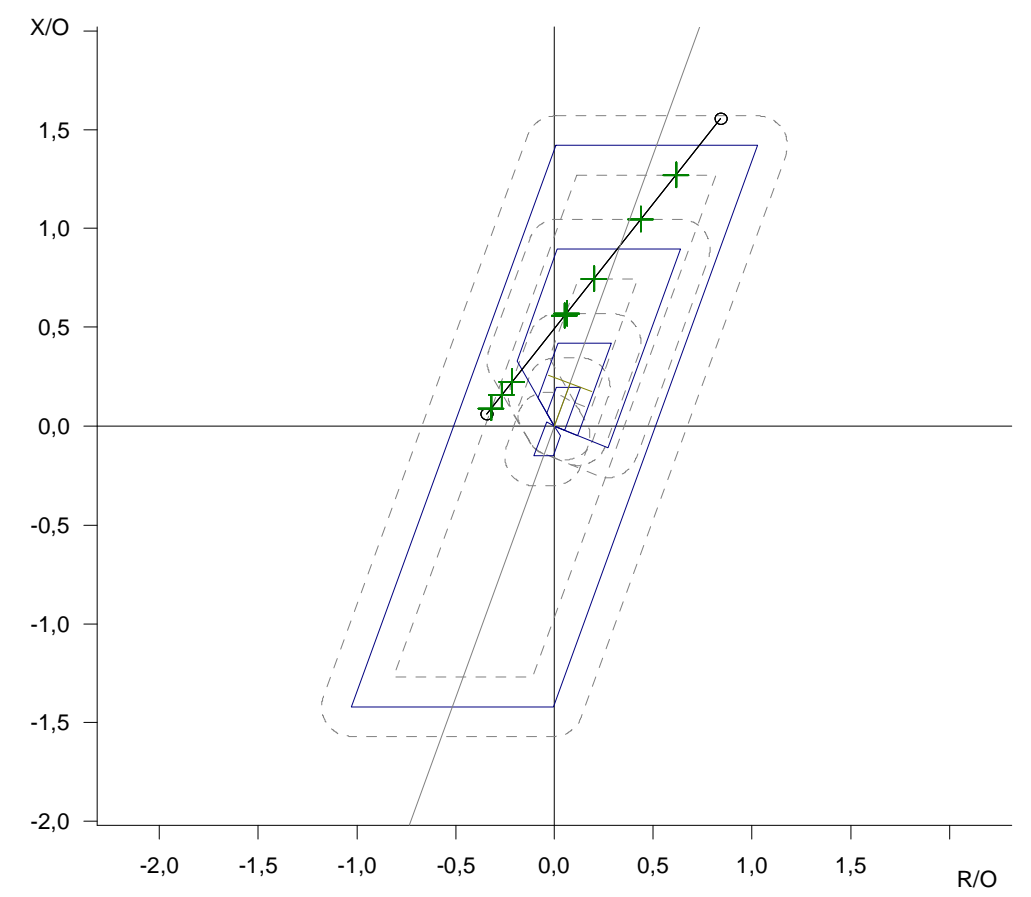

Fig. 7. A line for test of distance protection relay

Table 5. Results from testing of distance protection relay

\begin{tabular}{|c|c|c|c|c|c|c|}
\hline$|\mathbf{Z}|$ & Phi & $\mathbf{t}_{\text {nom }}$ & $\mathbf{t}_{\text {act }}$ & Dev. & ITest & Result \\
\hline $332.0 \mathrm{~m} \Omega$ & $164.32^{\circ}$ & $5.000 \mathrm{~s}$ & $5.054 \mathrm{~s}$ & $1.08 \%$ & $10.00 \mathrm{~A}$ & Passed \\
\hline $308.9 \mathrm{~m} \Omega$ & $149.12^{\circ}$ & $5.000 \mathrm{~s}$ & $5.054 \mathrm{~s}$ & $1.082 \%$ & $10.00 \mathrm{~A}$ & Passed \\
\hline $309.2 \mathrm{~m} \Omega$ & $133.56^{\circ}$ & $5.000 \mathrm{~s}$ & $5.059 \mathrm{~s}$ & $1.17 \%$ & $10.00 \mathrm{~A}$ & Passed \\
\hline $560.2 \mathrm{~m} \Omega$ & $84.72^{\circ}$ & $1.000 \mathrm{~s}$ & $1.034 \mathrm{~s}$ & $3.43 \%$ & $10.00 \mathrm{~A}$ & Passed \\
\hline $573.3 \mathrm{~m} \Omega$ & $83.87^{\circ}$ & $1.000 \mathrm{~s}$ & $1.034 \mathrm{~s}$ & $3.43 \%$ & $10.00 \mathrm{~A}$ & Passed \\
\hline $772.5 \mathrm{~m} \Omega$ & $74.94^{\circ}$ & $1.000 \mathrm{~s}$ & $1.034 \mathrm{~s}$ & $3.42 \%$ & $10.00 \mathrm{~A}$ & Passed \\
\hline $1.134 \Omega$ & $67.25^{\circ}$ & $5.000 \mathrm{~s}$ & $5.034 \mathrm{~s}$ & $0.688 \%$ & $10.00 \mathrm{~A}$ & Passed \\
\hline $1.412 \Omega$ & $64.11^{\circ}$ & $5.000 \mathrm{~s}$ & $5.034 \mathrm{~s}$ & $0.678 \%$ & $10.00 \mathrm{~A}$ & Passed \\
\hline
\end{tabular}

\section{Conclusion}

The issue of testing protective relays is quite difficult and even before the actual deployment of the relay into operation is required functional and system 
testing. The aim of this paper is to describe a testing method of the description of the protective relay SIEMENS SIPROTEC 7SA611.

This protection relay includes protection distance between overhead lines and cable lines. In view of the fact that it is a digital relay, this device has a more security features that have been described at the beginning of article. For the test this digital protective relay one protective function was chosen, "ANSI 21 - Distance Protection".

In total, two tests were carried out in different parts of the protection zones. As shown in the attached tables, the actual tripping time in individual testing points deviates from the preset minimum time and therefore protective relay can be used in operation.

\section{References}

[1] Kolcun M., Griger V., Beňa L., Rusnák J.: Prevádzka elektrizačnej sústavy, Košice 2007. ISBN 978-80-8073-837-2

[2] Lumnitzer E., Drahoš R., Liptai P.: Elektromagnetické polia v životnom a pracovnom prostredi Objektivizácia a hodnotenie faktorov prostredia, 1. vyd - Košice, Technická univerzita, 2014, s. 96. ISBN 978-80-553-1910-0.

[3] Chladný V., Janíček F., Belaň A.: Digitálne ochrany v elektrizačných sústavách, Košice 2003. ISBN 80-89061-73-7

[4] Liptai P., Moravec M., Lumnitzer E., Lukáčová K.: Impact analysis of the electromagnetic fields of transformer stations close to residential buildings. In: SGEM 2014, volume 1, p. 17-26, 2014, STEF92 Technology, p. 355-360. ISBN 978-6197105-17-9.

[5] Siemens, Siprotec Distance Protection 7SA611, Manual, 6.2013.

\section{WERYFIKACJA OPERACJI PRZEKAŹNIKA ZABEZPIECZENIOWEGO ODLEGLOŚCIOWEGO}

Streszczenie

W artykule opisano możliwości testowania cyfrowego przekaźnika zabezpieczeniowego. W związku z tym w pracy zostały opisane funkcje ochronne przekaźnika zabezpieczeniowego odległościowego SIEMENS SIPROTEC 7SA611 i wykorzystanie ich do ochrony linii energetycznych. Ostatnia część artykułu zawiera elementy testowania zabezpieczenia odległościowego wraz z kilkoma odmianami w module testowania „Advance distance”.

Słowa kluczowe: przekaźnik zabezpieczający, testowanie pracy, metoda pośrednia

DOI: $10.7862 / \mathrm{re} .2017 .2$

Tekst złożono w redakcji: marzec 2017

Przyjęto do druku: maj 2017 